\title{
Moose Summer Diet From Feces and Field Surveys: A Comparative Study
}

\author{
Hilde Karine Wam ${ }^{1}$ and Olav Hjeljord ${ }^{2}$ \\ Authors are ${ }^{1} \mathrm{PhD}$ student and ${ }^{2}$ Associate Professor, Department of Ecology and Natural Resource Management, Norwegian University of Life Sciences, \\ Box 5003, 1432 Ås, Norway.
}

\begin{abstract}
Microhistological analysis of feces is the most applied noninvasive method for assessing diets of wild ungulates. However, the method is complicated by differential digestibility of forage species. To evaluate the efficacy of this method in quantifying browse components in summer diets of moose (Alces alces L.) on Norwegian rangelands, we compared it to parallel field surveys of browsed vegetation on the same range. Although the same principal diet components were identified in the feces and in the field, there were consistent discrepancies between the two methods in estimated proportional diet contents. Birch (Betula spp.) showed the highest field:fecal ratio: $3.3 \pm 0.50$ compared to $0.9 \pm 0.16$ for Salix spp., $0.8 \pm 0.16$ for aspen (Populus tremula L.), and $0.6 \pm 0.12$ for rowan (Sorbus aucuparia L.). Until in vivo fecal correction factors for differential forage digestibility are available, we caution against broad application of fecal analyses for estimating proportions of browse in moose diet. Although we could not determine the exact amount of discrepancy implicit in each method, previous studies of moose summer diet in the area clearly indicate that fecal analyses gave a less accurate representation of actual moose browse diet than did the field survey. Fecal analyses are nevertheless needed to identify moose diet components other than browse, which are not easily obtained from field surveys.
\end{abstract}

\begin{abstract}
Resumen
El análisis microhistológico de heces es el método no-invasivo de evaluación de dietas de herbívoros silvestres más utilizado. Sin embargo, la digestibilidad diferencial de las especies forrajeras complica el uso de esta técnica. A fin de evaluar la eficacia de esta técnica en cuantificar componentes de ramoneo en dietas de verano de alces (Alces alces L.) en pastizales naturales de Noruega, comparamos el análisis microhistológico con evaluaciones de campo de vegetación ramoneada realizadas en forma paralela en el mismo sitio. Si bien los mismos componentes dietarios principales fueron identificados en heces y en el campo, se verificaron discrepancias consistentes entre ambos métodos en las proporciones de componentes dietarios estimados. Betula spp. exhibió la relación campo:fecas mas elevado: $3,3 \pm 0,50$ comparado con 0,93 $\pm 0,16$ para Salix spp., 0,8 \pm 0.16 para Populus tremula L., y 0,6 \pm 0,12 para Sorbus aucuparia L. Hasta tanto estén disponibles factores de corrección fecales in vivo que tomen en cuenta la digestibilidad diferencial de los forrajes, aconsejamos precaución en la aplicación amplia de análisis de fecas para estimar proporciones de forraje ramoneable en la dieta de alces. Si bien no pudimos determinar la magnitud exacta de discrepancia implícita en cada método, estudios anteriores de dietas estivales de alces en este sitio claramente indican que el análisis de fecas produjo una representación menos precisa de la dieta de ramoneo real de alces comparado con el relevamiento de campo. Los análisis de fecas son necesarios, sin embargo, para identificar componentes no ramoneables de la dieta de alces, que no pueden ser obtenidos fácilmente mediante relevamientos de campo.
\end{abstract}

Key Words: bite count, management, ruminant, technique

\section{INTRODUCTION}

Identifying species composition of animal diets is fundamental to many aspects of wildlife research and rangeland management. The most applied noninvasive methods for analyzing diets of wild, large herbivores can be summarized as follows (Ortmann et al. 2006): 1) microhistological analyses of feces; 2) direct observation of foraging animals, often termed bite counts (Hubbard 1952); and 3) surveying bite marks on vegetation in the field. Additional lesser-used methods with restricted applications are $\mathrm{n}$-alkane analysis of feces (Dove and Mayes 1991) and near infrared spectroscopy of feces (e.g., Walker et

Research was funded by the Research Council of Norway, the municipalities of Vegårshei, Larvik, Aurskog, Åsnes, and Gjøvik, as well as the moose management region "Drammen Sør."

Correspondence: Hilde Karine Wam, Dept of Ecology and Natural Resource Management,

Norwegian University of Life Sciences, Box 5003, 1432 Ås, Norway. Email: hilde.wam@umb.no

Manuscript received 3 April 2009; manuscript accepted 19 December 2009. al. 1998). The use of DNA analyses of fecal material is promising, but still unexplored for large herbivore diets (Ortmann et al. 2006).

Albeit frequently used for domestic livestock, direct observations of foraging animals are seldom applied to wild ungulates because of their elusive nature. The method might be more suitable for the less elusive megaherbivores such as the giraffe (Giraffa camelopardalis L.; Parker and Bernard 2006). An alternative to directly observing the foraging animal is to follow its tracks and count bite marks on browsed vegetation along the path (e.g., Vivås and Sæther 1987; Sæther et al. 1989; Shipley et al. 1998). However, this method only is suitable to situations with adequate snow cover, and hence, only can be used to estimate winter diets (although it has been used on bare ground as well; Knowlton 1960). For noninvasive estimation of summer diets of wild ungulates, only fecal analyses and field surveys of browsed vegetation are feasible. Available literature indicates that fecal analyses have been used most frequently 
(Dearden et al. 1975; Cuartas and Garcia-Gonzalez 1996; Mayes and Dove 2000).

Fecal analyses necessitate correction factors to adjust for differential digestibility of plants (Pulliam 1978). Such correction factors only might be accurately determined using fistulae on tamed animals, or by feeding known diets to animals in controlled settings. Unfortunately, even these approaches cannot adequately mimic the more diverse diets of free-roaming animals, particularly because digestibility of one species might be influenced by other species in the digestive tract (Gill 1972; Westoby 1978; Hjeljord et al. 1982; Gill et al. 1983; Bernays et al. 1994). Time and funding needed for such experiments is beyond the reach of most research programs. Consequently, a comprehensive set of digestibility correction factors is available for only a few wild herbivores.

To evaluate the efficacy of fecal analyses for quantifying browse in summer diets of moose on Norwegian rangelands, we compared this method to parallel field surveys of browsed vegetation on the same range. We limited our study to shrubs and trees (hereafter termed browse), because there are no uniform quantitative browsing indices applicable to both browse and other moose forage. In order to have a large gradient in diet diversity, we allocated our sampling in space (i.e., over several ranges) rather than in time. We hypothesized that 1) due to, for example, differential digestibility of species, there would be discrepancies between the two methods in their estimation of proportional diet contents on a given range; 2) these discrepancies would be consistent across ranges; or 3) alternatively, that the discrepancies would vary with diet compositions (i.e., vary between ranges). If the latter applies, fecal analyses are further complicated because it might be necessary to develop site-specific correction factors for digestibility in moose.

\section{METHODS}

\section{Data Collection}

The study was conducted in July and August from 2005 to 2008. These are the months with the highest species diversity in moose diet (Hjeljord et al. 1990). Our study area comprised 11 moose ranges of approximately 10000 ha each in south-central Norway (lat $58^{\circ} 45^{\prime} \mathrm{N}-60^{\circ} 52^{\prime} \mathrm{N}$, long $08^{\circ} 51^{\prime} \mathrm{E}-12^{\circ} 13^{\prime} \mathrm{E}$ ). The ranges were selected to represent separate ecological entities, i.e., with no extensive movement of moose between ranges. Each range only was surveyed in $1 \mathrm{yr}$, and all but four ranges were sampled for feces in the same year as the field surveys. Due to time constraints, the four remaining ranges were sampled for feces in 2005, and surveyed in the field the next year. We included these ranges in the data set because there were no differences in plant growth conditions (precipitation and mean day temperature) between May-August of 2005 and 2006 (generalized linear model interactions "range $\times$ year $\times$ category," where category is whether temperature or precipitation $F_{3,57}=0.1, P=0.720$; “year $\times$ category:" $F_{1,57}=0.2$, $P=0.638$ ).

We define browse as bush and tree species only, and not woody plants in the field layer (e.g., bilberry, Vaccinum myrtillus L.). The following species or species groups were included as browse in this study: birch (Betula spp.), rowan
(Sorbus aucuparia L.), aspen (Populus tremula L.), Salix spp., oak (Quercus spp.), and "other deciduous" (all other deciduous species). Conifers were not included because these ordinarily are not eaten by moose during summer in Norway (Bergström and Hjeljord 1987).

We did field surveys of moose summer foraging by continuously counting all trees with browseable parts within moose reach (i.e., at a height of 30-300 cm) along 2-m-wide belt transects. Trees $<30 \mathrm{~cm}$ are submerged in the herbaceous layer and were omitted in our survey because they rarely are browsed by moose due to conformational constraints (Hjeljord et al. 1990, using close-range observations of radiocollared, wild moose). Trees with stems branching $<5 \mathrm{~cm}$ above the soil level were counted as separate individuals. For each tree counted, we noted whether it had been browsed by moose in the current summer (i.e., showed signs of bites or stripping of leaf, bark, shoots, or buds). On average we walked $7 \pm 0.4$ transects per range, and $7.6 \pm 0.33 \mathrm{~km}$ per transect. We counted a total of 143815 trees (1997 \pm 135.0 per transect), of which 23360 had been browsed by moose $(336 \pm 26.2$ per transect). Transects were systematically distributed on the range, neither randomized nor targeted towards particular spots. Care was taken to have transects both across and along the range's valleys and hills. Roe deer (Capreolus capreolus L.) are sympatric with moose on all the ranges, and on two ranges there were also sheep and/or cattle (ranges 4 and 11). However, the density of these other herbivores is very low, and we believe they caused only insignificant bias in our data (see also DISCUSSION).

To quantify biomass removed by moose per browsed tree of the various forage species, we also surveyed browse in a plot survey. Transects were laid out in the same manner as the belt transects, with $12-\mathrm{m}^{2}$ circle plots placed every $15 \mathrm{~m}$ (as measured by steps) in young forest (tree height $<4 \mathrm{~m}$ ) and every $75 \mathrm{~m}$ in older forest (tree height $>4 \mathrm{~m}$ ). On each plot we sampled one tree of each browse species that was present on the plot (excluding the mixed group "other deciduous"). Trees were selected with respect to both shoot biomass and browsing intensity of the species within the plot. We sampled two trees if the species had two clearly different heights or browsing intensities within the plot. For each tree we counted the number of shoots browsed in the current summer, and measured the length of a representative unbrowsed shoot (current year's growth). On average we sampled $140 \pm 16.6$ trees per range and species (ranging from $50 \pm 11.8$ per range for aspen to $258 \pm 33.7$ per range for birch).

We quantified leaf production on the range with the least browsing pressure (range 3). Using a 50-g spring scale (0.5-g precision; Pesola AG, Baar, Switzerland), we measured shoot lengths and weighed shoots and leaves on trees with negligible apparent browsing ( $n=30$ trees per species). We limited the sampling to sites of intermediate soil fertility. Trees were subjectively selected in order to evenly represent the $30-300 \mathrm{~cm}$ height range. We measured three shoots per tree: one at onethird and one at two-thirds of crown height, as well as the long shoot (the uppermost shoot). Salix spp. were sampled equally in young and old forests (because of different growth forms); all other species were sampled in young forest only. The survey was done over 2 yr (15 July-15 August in 2006 and 2007). To avoid effects of date and year, sampling of each species was 
evenly spread within the study period by measuring an equal number of trees per species on any given survey day.

We collected $19 \pm 1.9$ fecal samples from moose per range (one sample taken from each group of pellets). Sampling of feces was evenly distributed on the range, either systematically by searching with hunting dogs (Norwegian grey elkhound), or opportunistically when doing the field surveys. Based on activity patterns of radiocollared Norwegian moose (Sæther et al. 1992), we set $2 \mathrm{~km}$ between fecal deposits as a minimum distance threshold in order to obtain samples from different moose.

We analyzed plant epidermal fragments microscopically using the procedures of Garcia-Gonzalez (1984). After thawing, about five pellets from each fecal deposit were lightly ground in a mortar. We transferred approximately $1 \mathrm{~mL}$ of the sample to a test tube containing $4 \mathrm{~mL}$ of concentrated nitric acid. The tube was placed in boiling water for $1 \mathrm{~min}$, the contents then diluted with $200 \mathrm{~mL}$ water and boiled for another $4 \mathrm{~min}$. We next passed the suspension through 1.00$\mathrm{mm}$ and $0.20-\mathrm{mm}$ sieves, rinsed with water, and conserved the $0.20-\mathrm{mm}$ fraction in a mixture of $85 \%$ ethanol (of $70 \%$ solution), $10 \%$ formalin (of $40 \%$ solution), and $5 \%$ glacial acetic acid. The fragments were dispersed on microscope slides in a $50 \%$ aqueous solution of glycerine, fixed with $20 \times 40 \mathrm{~mm}$ cover slips, and sealed with nail varnish. Two slides were made from each sample. All fragments (not just browse) partly or in whole dissecting $40 \times 1$-mm-long transects were counted, and if possible, identified to species or genus, with a minimum of 200 fragments in total per slide (running out the last started transect). On average we identified $446 \pm 1.7$ epidermal fragments per fecal sample $(n=206)$. When we report percent diet content of browse as found in the feces, this value is the species proportions calculated among identified browse fragments only.

\section{Data Analyses}

We analysed data with SAS statistical software (release 9.2, SAS Institute Inc. 2008). All measures are given as mean \pm SE if not otherwise stated. For most species, the number of browsed shoots per tree was highly skewed towards the low numbers (i.e., a right-sided tail), and for these we used the median.

We checked for sufficiency of fecal and tree count sample sizes by randomly and independently drawing $3,6,9, \ldots, n_{\max }$ of our samples and plotting the standard error of their species diet content against sample size. For all species and all ranges, the standard errors of percent diet content were visually stabilized at $<10 \%$ for $n_{\max }(3.7 \pm 0.55 \%, n=66$ for fecal, and $4.9 \pm 0.73 \%, n=66$ for tree-count). For the fecal samples, this corresponds well to data by Anthony and Smith (1974), who found that 15 fecal samples were a minimum to cover the individual variance in diets of deer populations.

We calculated biomass removed by moose per browsed tree as follows: from the detailed measurements taken on range 3 we fitted linear regression equations of leaf biomass $(\mathrm{g})$ in relation to shoot length $(\mathrm{cm})$. For Salix spp., which had been sampled in both young and old forest, we used the mean of the measures taken in the two age classes. We applied the equations to range-specific data to obtain a range's species-specific average of biomass removed per browsed tree. The speciesspecific biomass removed per browsed tree all were normally distributed across ranges with the exception of Salix spp., for which approximately all trees on range 11 were sallow (Salix caprea L.), whereas on the other ranges the group was more evenly composed of several species. We used a balanced twoway analysis of variance to test whether the biomass removed per browsed tree differed between species and ranges, choosing not to omit the outlier (range 11) for this particular purpose. For simplicity of discussion, we report biomass removed per browsed tree pooled for all ranges, but all related tests were run with range-specific data. Biomass removed per browsed tree was multiplied by the tree counts in order to find biomass browsed per species on each range. When we present percentage diet content as found in the field surveys, this represents the proportion of total browsed biomass of browse species.

In order to quantify the overlap between fecal and field-survey diets we calculated the Schoener's index (Schoener 1968):

$$
R_{0}=1-0.5 \cdot \sum\left|p_{i j}-p_{i k}\right|,
$$

where $p_{i j}$ and $p_{i k}$ are the proportions of species $i$ in the diet as found by method $j$ and $k$, respectively. Although a significance decision level to determine similar diets has been suggested for this index (Scrimgeour and Winterbourn 1987), we believe it is not suitable for correlated data (it was originally suggested for comparing diets among animals or populations, not survey methods). Instead, we used generalized mixed models (GLIMMIX in SAS), which accounts for interspecific dependency in the data. Oak was grouped with "other deciduous" to avoid too many cells with a zero value (oak is endemic to the western parts of our study area). We initially fitted a model with diet contents treated as "pseudo-binomial" variables because the underlying tree-counts had a binomial outcome, and the epidermal fragment counts were a Poisson approximation. However, we concluded (based on the scaled Pearson statistic $\chi^{2} /$ degrees of freedom as well as residual displays) that this was not appropriate. We therefore used and found appropriate the variance function $\operatorname{var}_{\text {prop }}=\mu^{2}(1-\mu)^{2}($ McCullagh and Nelder 1989), in which the distribution of data is treated as unknown, and consequently GLIMMIX uses a quasi-likelihood estimation technique. Because we were interested in the three-way interaction effect "method $\times$ species $\times$ range" (hypotheses 2 and 3 ) as well as the two-way interaction "method $\times$ species" (hypothesis 1 ), we fitted a saturated model (the three main effects and all possible interaction effects) with the intention of performing backward elimination (e.g., Agresti 1996). We report type-III tests of fixed effects and exact $P$ values for two-sided alternatives.

We used paired Student's $t$ tests to check whether one method consistently gave higher or lower values than the other method (testing per species across ranges, results are given as one-sided alternatives). We thereafter quantified the speciesspecific methodological discrepancy as a ratio:

$$
d i v_{i, j}=\frac{\left(p_{i j, f i e l d}+1\right)}{\left(p_{i j, f e c a l}+1\right)},
$$

where $p_{i j, \text { field }}$ and $p_{i j, f e c a l}$ are the percent diet content of species $i$ on range $j$ as found by the field surveys and the fecal analyses, respectively. We added an increment of 1 to the percentages to 
Table 1. Linear regression analyses of leaf biomass $(\mathrm{g})$ in relation to shoot length $(\mathrm{cm})$ for current year's growth of unbrowsed deciduous trees in south-central Norway (lat $59^{\circ} 22^{\prime} \mathrm{N}$, long $10^{\circ} 17^{\prime} \mathrm{E}$ ). Three shoots measured at various crown heights per tree ( $n=30$ trees per species) on intermediate soil fertility in July-August 2006 and 2007 (an equal number of trees were measured per species per survey day to avoid effect of date).

\begin{tabular}{lccc}
\hline Species & Regression equation & SE of regression coefficients ${ }^{1}$ & Statistics \\
\hline Birch & $y=0.6+0.17 x$ & $2.04,0.041$ & $t_{29}=4.1, R^{2}=0.378, P<0.001$ \\
Rowan & $y=0.2+0.25 x$ & $0.68,0.042$ & $t_{29}=5.8, R^{2}=0.546, P<0.001$ \\
Salix spp. & $y=0.1+0.10 x$ & $0.21,0.012$ & $t_{29}=9.1, R^{2}=0.746, P<0.001$ \\
Aspen & $y=1.6+0.12 x$ & $0.43,0.012$ & $t_{29}=10.0, R^{2}=0.782, P<0.001$ \\
Oak & $y=-1.4+0.46 x$ & $1.02,0.048$ & $t_{29}=9.7, R^{2}=0.771, P<0.001$ \\
\hline
\end{tabular}

${ }^{1} \mathrm{y}$-intercept and slope, respectively.

avoid zero values. Because there was much variation in discrepancy ratios between ranges, we present overall speciesspecific ratios obtained in two ways: 1) by first calculating ratios per range, and then taking the average; and 2) by first taking the average of diet contents across ranges, and then calculating the ratios. Range 11 had an extreme ratio for Salix spp., and was omitted from the average ratio calculations. Because we found that the discrepancies might have been affected by diet composition, we used multiple regression analysis to examine which diet components were most associated with the discrepancy on a given range, regarding the ratios as statistically independent of the percentages.

\section{RESULTS}

The estimated biomass removed by moose per browsed tree in the field surveys varied both between species $\left(F_{5,65}=5.3\right.$, $P=0.001$; Tables 1 and 2$)$, and between ranges $\left(F_{10,65}=3.1\right.$, $P=0.004)$. For the three most important browse species (birch, rowan, and Salix spp.), the number of shoots browsed per plant contributed the most to this variance, because the biomass available per shoot were approximately the same.

In the microhistological analyses of the feces, browse species together made up $50 \pm 1.8 \%$ of all identified fragments per sample $(n=206)$, ranging from $27 \%$ to $80 \%$. The remaining contents were dominated by bilberry $(19 \pm 1.0 \%)$, grasses and grass-like plants (species of Poaceae and Cyperaceae; $10 \pm 1.2 \%$ ), and raspberry (Rubus idaeus L.; $9 \pm 0.9 \%$ ). There was no linear relationship between percent browse in feces and diet overlap between the two methods (Schoener's index of fecal vs. field $)$ across ranges $\left(t_{10}=0.21, R^{2}=0.005\right.$,
$P=0.835)$. Thus, the agreement between the two methods did not vary with fragment sample size within our data range.

We identified the same principal diet components with the fecal analyses and the field surveys (Fig. 1); birch, rowan, Salix spp., and aspen together made up $90 \%$ or more of the browse with both methods on all but the two southernmost ranges, where oak was also important in the diet. In the field surveys, birch and then rowan were the two most frequently browsed species, whereas in the fecal analyses, rowan and then Salix spp. were both found to be more frequent in the diet than birch.

The two methods did not give the same proportional content, neither across ranges nor within each range. In the generalized linear model, both the three-way interaction effect "method $\times$ species $\times$ range" $\left(F_{38,1248}=7.5, P<0.001\right)$ and the two-way interaction "method $\times$ species" $\left(F_{4,1} 248=91.3, P<0.001\right)$ were highly significant. Thus, the discrepancies between the two methods varied not only with species per se, but the speciesspecific discrepancy also varied between ranges (and hence, possibly the diet compositions). The effects were not artifacts of our estimations of biomass removed per browsed tree, because the same model that ran with the tree count frequencies directly was also highly significant $(P<0.001)$.

The species-specific discrepancies were consistent for three of the four main species: the contribution of rowan $\left(t_{11}=2.9\right.$, $P=0.009$, pair-wise testing across ranges $)$ and aspen $\left(t_{11}=2.1\right.$, $P=0.032)$ to the moose diet was overestimated in the fecal analyses compared to in the field surveys, whereas the relationship was opposite for birch $\left(t_{11}=-6.3, P<0.001\right)$. For Salix spp. there was variation both ways, and so the overall discrepancy was not significant $\left(t_{11}=1.2, P=0.125\right)$. However, omitting the outlier range 11 gave significant test results also for Salix spp. $\left(t_{10}=2.0, P=0.037\right)$.

Table 2. Leaf biomass $(\mathrm{g})$ available and removed by moose per browsed tree (Alces alces L.) in south-central Norway (2005-2008). Mean \pm SE or median (quartiles) among 11 ranges (lat $58^{\circ} 45^{\prime} \mathrm{N}$, long $8^{\circ} 51^{\prime} \mathrm{E}-$ lat $60^{\circ} 42^{\prime} \mathrm{N}$, long $12^{\circ} 13^{\prime} \mathrm{E}$ ).

\begin{tabular}{lcccc}
\hline \multicolumn{1}{c}{ Species } & \multicolumn{1}{c}{$\begin{array}{c}\text { Average shoot } \\
\text { length }(\mathrm{cm})\end{array}$} & $\begin{array}{c}\text { Available leaf }(\mathrm{g}) \\
\text { per shoot }^{1}(x)\end{array}$ & $\begin{array}{c}\text { No. of shoots browsed } \\
\text { per tree }(y)\end{array}$ & $\begin{array}{c}\text { Leaf removed per browsed } \\
\text { tree }(\mathrm{g})(z=x \cdot y)\end{array}$ \\
\hline Birch & $12.3 \pm 0.16(n=3260)$ & $2.8 \pm 0.14$ & $4(2,8)^{2}$ & 11.2 \\
Rowan & $9.3 \pm 0.22(n=2339)$ & $2.5 \pm 0.36$ & $2.2(2.00,2.69)$ & 5.9 \\
Salix spp. & $16.8 \pm 0.53(n=706)$ & $2.1 \pm 0.21$ & $5.1(3.11,6.20)$ & 9.9 \\
Aspen & $13.6 \pm 0.53(n=577)$ & $3.0 \pm 0.18$ & $2.5(2.00,2.80)$ & 7.4 \\
Oak & $7.0 \pm 0.28(n=405)$ & $1.8 \pm 0.09$ & $4(2,6)^{2}$ & 8.6 \\
"Other deciduous"3 & $11.8 \pm 1.70$ & $2.4 \pm 0.14$ & $3.5(3.32,4.08)$ & 8.2 \\
\hline
\end{tabular}

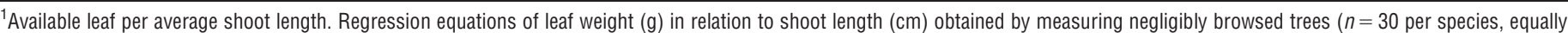
distributed within $30-300-\mathrm{cm}$ tree height) on intermediate soil productivity on a range with low browsing pressure.

${ }^{2}$ Birch ( $n=248$ trees) and oak ( $n=50$ trees) measured on one and two ranges, respectively. The remaining species measured on all ranges.

${ }^{3}$ Mean (or median) of the above five browse species were used to represent values for this mixed species group. 


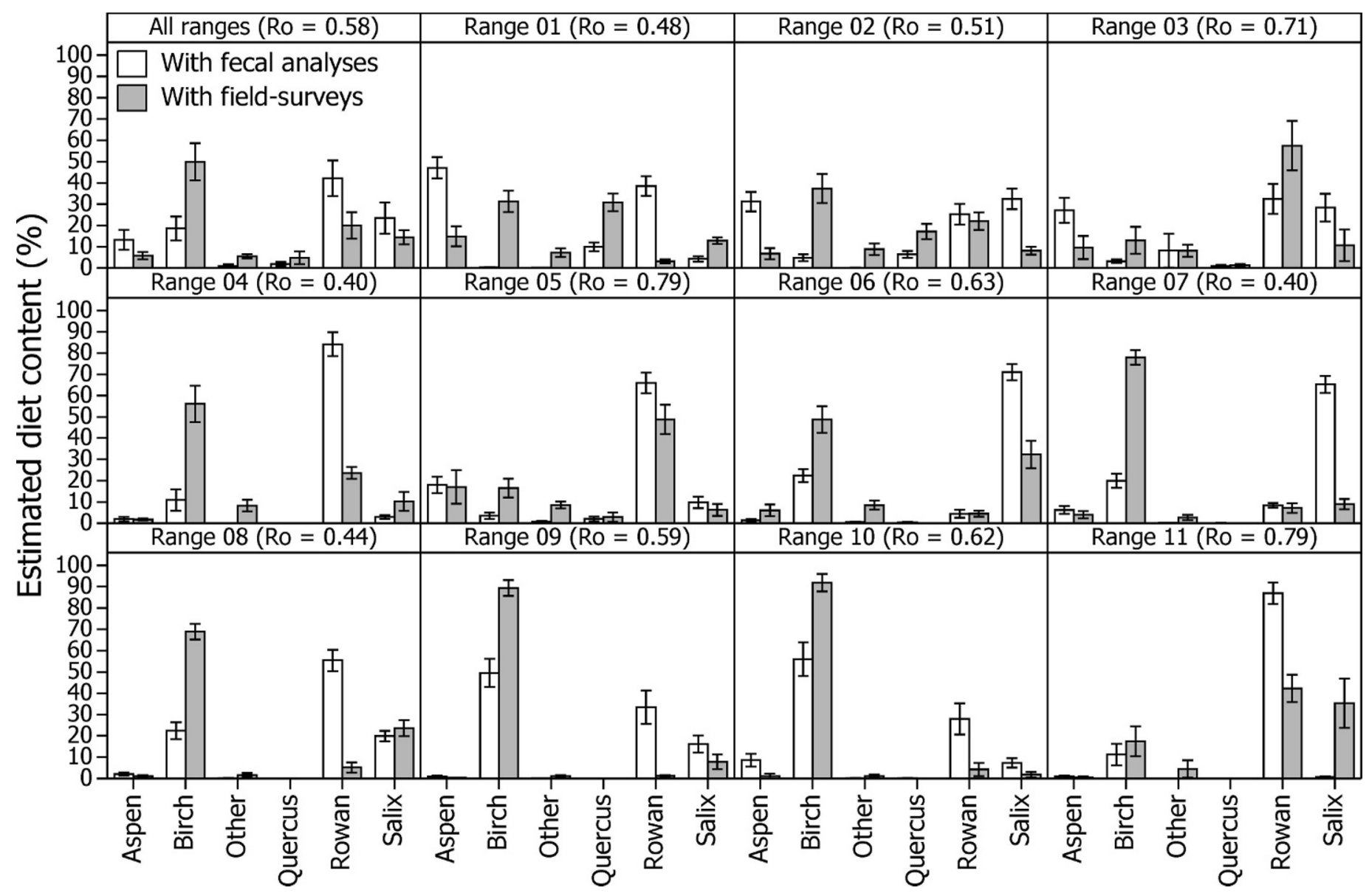

Figure 1. Percentage species contribution among browse in moose (Alces alces L.) summer diet on 11 ranges in south-central Norway (20052008), as found by fecal analyses ( $n=206$ fecal deposits) and field surveys of browsed vegetation $(n=23360$ trees). Bars are mean \pm SE. $R_{0}=$ Schoener's index of diet overlap between the two methods.

The consistency of the discrepancies is best illustrated by a scatter plot (Fig. 2), where the observations should lie consequently on one side of the straight line $y=x$. For birch and aspen the methods seemed to diverge more with higher diet contents. If we remove two outliers from the data (range 3 and range 11), even rowan and Salix spp. seem to follow the pattern of increased discrepancy with higher diet proportions. The plot also supports the assumption that very low densities of sheep and cattle on ranges 4 and 11 did not constitute bias in our data (the ranges are not distinct outliers to the right-side lower corner of the figure).

Birch had the highest field:fecal ratio: $3.3 \pm 0.50$ compared to $0.9 \pm 0.16$ for Salix spp., $0.8 \pm 0.16$ for aspen, and $0.6 \pm 0.12$ for rowan (Fig. 3). In accordance with the significant "method $\times$ species $\times$ range" (i.e., species-specific discrepancies varied between ranges), taking the average of ratios calculated per range gave a different value than calculating the ratios from diet proportions that had been averaged across ranges (the latter ratios were 5.6 for birch, 0.7 for Salix spp., 0.5 for aspen, and 0.5 for rowan). We found no obvious patterns in diet composition and species-specific discrepancies, and the explanatory variables for the significant three-way interaction effect "method $\times$ species $\times$ range" remain unsolved.

\section{DISCUSSION}

Our study shows that the much-applied method of fecal analysis should be used with caution for estimating proportions of browse in the diets of moose (and hence, possibly other herbivore browsers with similar diets). We found support for hypothesis 1 (there were discrepancies between fecal and fieldsurvey estimations of diet proportions on a given range) as well as for hypothesis 3 (the discrepancies varied between ranges, and thus were possibly influenced by diet composition). There were consistent patterns in the discrepancies, which show that they were not simply coincidental results caused by inadequate sampling procedures. Previous knowledge of moose summer diet in the study area suggests that fecal results diverged more from the actual moose diet than did field-survey results. There is no doubt that birch is a far more important summer browse than shown by our fecal analyses on many of these ranges (see review by Hjeljord and Histøl 1999).

We will discuss four possible explanations for the discrepancies between our fecal analyses and field surveys in estimated proportional diet contents (not arranged in order of importance): 1) different time span of foraging; 2) differences in biomass removed per browsed tree of various forage species; 3 ) differential digestibility of various forage species; and 4) 


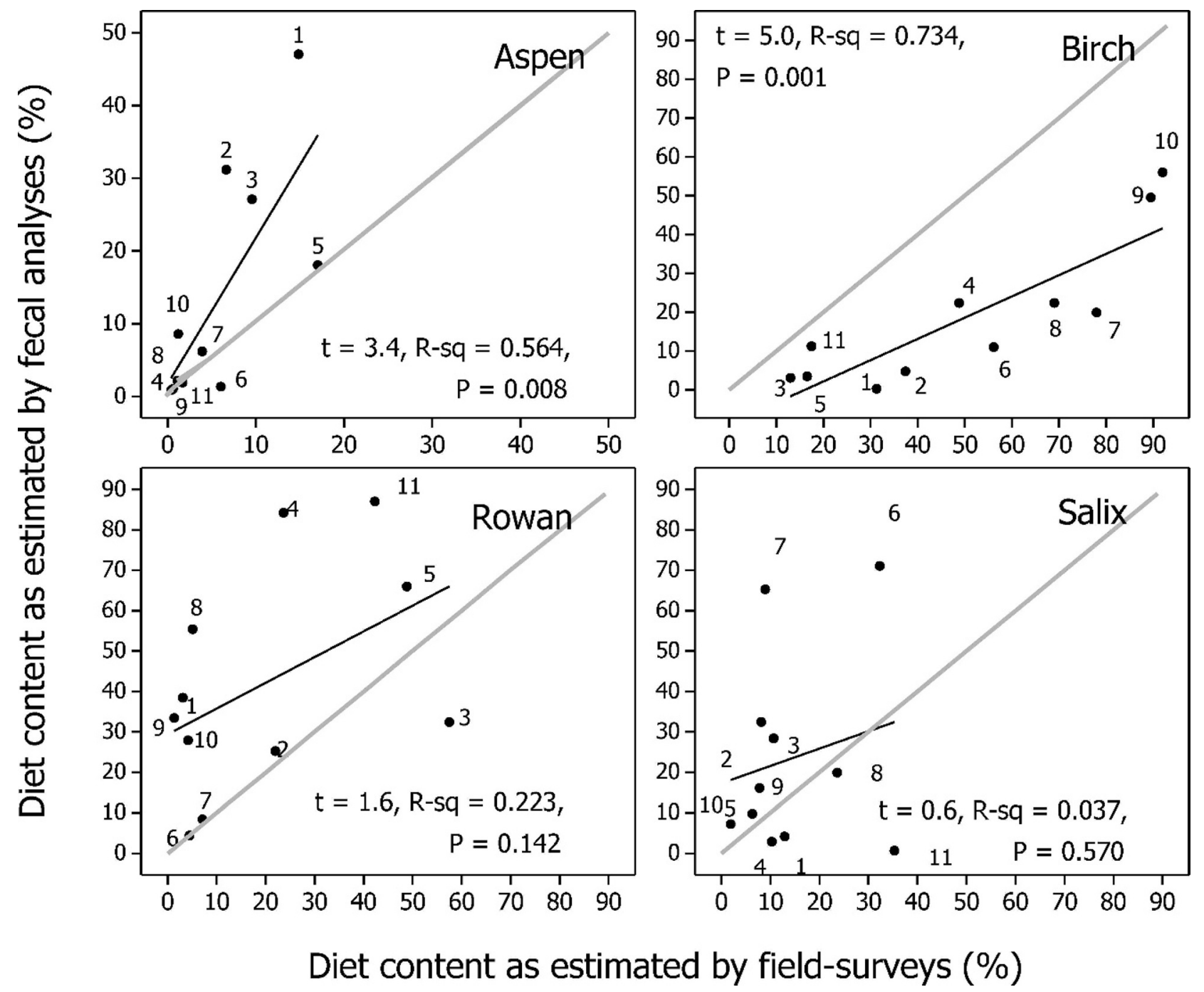

Figure 2. Percentage species contribution among browse in moose (Alces alces L.) summer diet in south-central Norway (2005-2008) as found by fecal analyses ( $n=206$ fecal deposits) compared to as found by field surveys of browsed vegetation ( $n=23360$ trees). Observations above or under the grey line $y=x$ indicate over- and underestimation, respectively, by fecal analyses compared to by field surveys. The black line is the linear regression fit.

consistent bias in epidermal fragmentation between forage species.

\section{Different Time Span of Foraging}

One simple explanation for the fecal vs. field-survey discrepancy could be that the two methods do not completely overlap in time. The field surveys reflect moose diet accumulated over the summer $(3.5 \mathrm{mo}$ at the most, but see later comment on birch regrowth). Each fecal deposit reflects moose diet within the last 1-4 d only (Hjeljord et al. 1982). The feces in our study were collected over $33.9 \pm 2.64 \mathrm{~d}$ per range with a mean collection day on 29 July (range 2 July-26 August). Hjeljord et al. (1984) found that from early (7 June-16 July) to late (20 August-15 September) summer, the ratio of browsed birch trees to browsed rowan trees decreased from 0.66 to 0.59 (on a range where the availabilities of birch and rowan were approximately equal). Likewise, the ratio found in a bite-count study of radiocollared moose on the same range decreased from 0.80 in early (May-June) to 0.71 in late (July-August) summer
(Hjeljord et al. 1990). In this study we found no relationship between collection date and birch diet content as expressed in the feces (however, we did not collect feces until the beginning of July).

The relative changes in birch consumption as indicated by Hjeljord et al. $(1984,1990)$ are noteworthy, but too small to explain a substantial amount of the discrepancy in our study. The possible bias stemming from early summer browsing on birch also is likely to have been partially counteracted by birch refoliation (Bergstrøm and Danell 1995).

\section{Differences in Biomass Removed Per Browsed Tree}

Moose are likely to browse fewer shoots per tree if a species is less preferred or more abundant (Vivås and Sæther 1987; this study). We therefore invested much effort to obtain data to sufficiently estimate the species-specific numbers of shoots browsed per tree as well as the available shoot lengths. The measures of foliage weight in relation to shoot length were taken on one range only, and might not adequately reflect the 


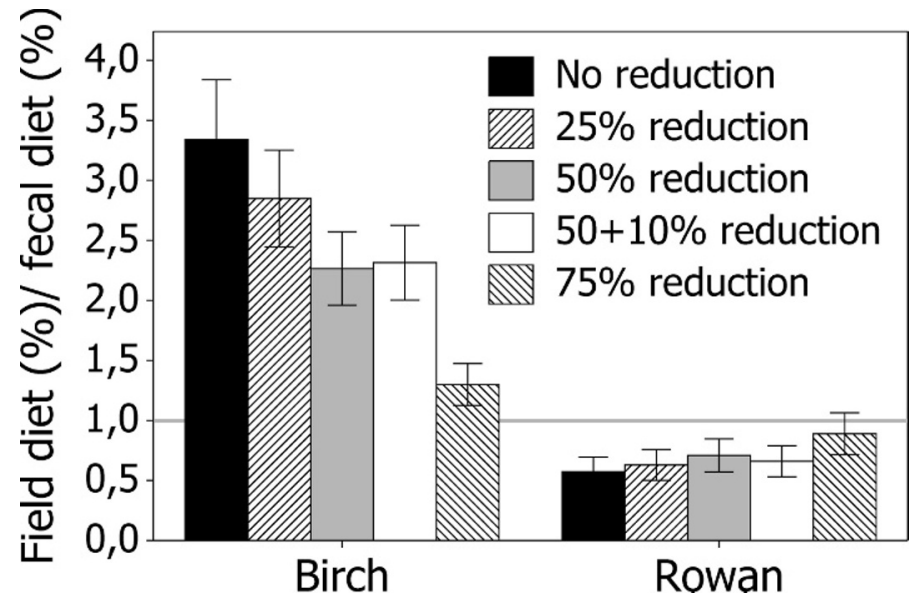

Figure 3. Ratios of estimated content of birch (Betula spp.) and rowan (Sorbus aucuparia L.) among browse in moose (Alces alces L.) summer diet in south-central Norway (2005-2008) as found by fecal analyses ( $n=206$ fecal deposits) and field surveys of browsed vegetation ( $n=23360$ trees). Ratios are calculated for various assumed degrees of leaf removal per browsed birch shoot in the field survey $(50+10 \%$ ratio includes a simultaneous $10 \%$ reduction in leaf removal of rowan shoots). Bars are mean \pm SE among 11 ranges.

variation that probably exists between ranges. Although the regression lines were highly significant, there was much variation and the sample size of 30 trees per species is rather small. On the other hand, leaf weights $(\mathrm{g})$ per shoot length $(\mathrm{cm})$ observed in our study compare well to the few other Scandinavian studies that have measured moose summer browse (Bergström and Danell 1995 on birch; Guillet and Bergström 2006 on Salix spp.). Furthermore, it is not likely that the negligibly browsed trees on range 3 should consistently have less birch foliage per shoot, and simultaneously have more foliage of the other main forage species (however, the seeming increase in discrepancies with higher diet proportions might be due in general to higher browsing intensity, and thus less biomass available per shootcentimeter than estimated from the measures taken on range 3 ).

There is one important variable in biomass removed per browsed tree that was not accounted for in our study: when moose browse on birch, they typically strip leaves from the shoot for less than $100 \%$ of the shoot length. If we correct the field-survey data accordingly, we find that a $25 \%$ reduction in biomass removed per browsed birch leads to a $15 \pm 2.4 \%$ $(n=11)$ decrease in the originally calculated diet proportions (and a comparable increase distributed among the other species). Even a $50 \%$ reduction only leads to a birch diet decrease of $32 \pm 4.4 \%$. With the reduced diet proportions, the field:fecal ratio for birch falls from 3.3 to 2.8 and 2.2, respectively (see Fig. 3). In the figure we also have illustrated a $50 \%$ reduction in birch with and without simultaneously reducing biomass of rowan $25 \%$ (which might, for example, occur if rowan is intensively browsed). The countereffect of this simultaneous reduction seems negligible. In order to balance the fecal and field estimates, a $>75 \%$ reduction in biomass removed per browsed tree is necessary. This would mean that moose should remove less than half as much foliage per browsed tree of birch compared to rowan (see Table 2), which does not seem very realistic.

\section{Differential Digestibility}

Fecal analyses in general overestimate the less digestible portions of an animal's diet (Cuartas and Garcia-Gonzalez 1996). Few studies have looked at bias within the ligneous species group (but see Dearden et al. 1975; Leslie et al. 1983), and there are no correction factors available to adjust for differential digestibility of browse species in the diet of moose. Although differential digestibility must have influenced our results to some degree, birch foliage would have to be several times more digestible than rowan foliage in order to explain a substantial portion of the discrepancies between our fecal and field-survey diet estimates. Such a magnitude does not seem likely. The winter twigs of birch are less digestible than the winter twigs of rowan (in vivo and in vitro, Hjeljord et al. 1982; in vitro, Shipley et al. 1998). Only one study has yet looked at summer digestibility: Hjeljord et al. (1990) found that the in vitro digestibility (using rumen liquor from sheep) of foliage was $49 \%$ for silver birch (Betula pendula Roth) and $64 \%$ for rowan. Using in vitro analysis with rumen liquor from cattle, we found less difference in summer foliage digestibility, but rowan was still the most digestible ( $88 \%$ vs. silver birch $82 \%$; H. K. Wam and O. Hjeljord, unpublished data, 2008, foliage collected from six different trees per species at Å, Norway). Although the in vitro technique using donor rumen liquor does not completely mimic moose digestion, the bias in its relative interspecific digestibility differences is unlikely to be manifold.

\section{Epidermal Bias}

There is general consensus that highly trained personnel are necessary to adequately detect and identify epidermal fragments (Ward 1970; Westoby et al. 1976; Holechek and Gross 1982; Holechek et al. 1982; Alipayo et al. 1992). We have not tested specifically for observer effects in our study. However, the results show that if there was observational bias, the majority of it was consistent (Fig. 2). One observational bias might be caused by ligneous parts having a lower proportion of identifiable epidermal fragments than leaves and buds (Holechek and Valdez 1985; Alipayo et al. 1992). The rowan plant parts browsed by moose on our study ranges were practically only leaves (rowan consisted almost entirely of trees whose current year's growth was severely stunted by moose browsing), whereas more ligneous material might have been consumed when the moose browsed on birch (the outer part of the shoot). This might have led to a consistent, albeit small, underestimation of birch compared to rowan in our fecal analyses.

Another and possibly more important source of bias is fragment size. In our experience, leaves of birch have more strength, and consequently disarticulate in larger fragments than rowan. This could create bias when counting the number of fragments. Although our samples were ground to a maximum of $0.2 \mathrm{~mm}$, there still was some variation in the fragment sizes. Unfortunately, we are unable to quantify this bias as long as we do not know the volume of what was originally ingested.

In summary, it seems likely that more than one of these four possible explanations have caused some bias in our fecal and/or field estimates of browse content in moose summer diet. 
Apparently, none of them can separately account for all the observed discrepancy. The first two (different time span and differences in removed biomass) might be quantified in future studies, but the latter two (differential digestibility and epidermal fragmentation) unfortunately are less likely to be solved (see introduction).

\section{IMPLICATIONS}

Although quantification of underlying factors for the observed fecal discrepancies is sought from a scientific point of view, what matters most to applied management is to be able to monitor shifts in major diet components within a moose population. These shifts can indicate declining or improving conditions. Based on our findings in this study, we believe that field surveys currently are a better option to monitor moose ranges than fecal analyses. Fecal analysis also demands more expertise and facilities than field surveys. On the other hand, field surveys of browsed vegetation cannot be used to assess the complete summer diet of moose, where herbaceous forage might contribute a substantial part. Fecal analyses are the only practical way to obtain data on moose foraging in the herbaceous layer.

\section{ACKNOWLEDGMENTS}

We thank Agnar Væringstad, Johan A. Berglund, Torbjørn Danielson, Kjell Greibesland, Knut Olav Fossestøl, and Trond Histøl for doing parts of the field work. We are also grateful to Erling Johan Solberg for valuable comments on an earlier draft of this manuscript.

\section{LITERATURE CITED}

Agresti, A. 1996. An introduction to categorical data analysis. New York, NY, USA: Wiley. $400 \mathrm{p}$.

Alipayo, D., R. Valdez, J. L. Holechek, and M. Cardenas. 1992. Evaluation of microhistological analysis for determining ruminant diet botanical composition. Journal of Range Management 45:148-152.

Anthony, R. G., And N. S. Smith. 1974. Comparison of rumen and fecal analysis to describe deer diets. Journal of Wildlife Management 38:535-540.

Bergstrøm, R., And K. Danell. 1995. Effects of simulated summer browsing by moose on leaf and shoot biomass of Betula spp., Betula pendula. Oikos 72:132-138.

Bergström, R., and 0. HJelJord. 1987. Moose and vegetation interactions in northwestern Europe and Poland. Swedish Wildlife Research Supplement $1: 213-228$.

Bernays, E. A., K. L. Bright, N. Gonzales, and J. Angels. 1994. Dietary mixing in a generalist herbivore: tests of two hypotheses. Ecology 75:1997-2006.

Cuartas, P., and R. Garcia-Gonzalez. 1996. Review of available techniques for determining the diet of large herbivores from their feces. Plant Ecology 99100:317-330.

Dearden, B. L., R. M. Hansen, and R. E. Pegau. 1975. Plant fragment discernibility in caribou rumens. In: J. R. Luick, P. C. Lent, D. R. Klein, and R. G. White [EDS.]. Proceedings of the First International Reindeer and Caribou Symposium. Biological papers, Special Report Number 1. Fairbanks, AK, USA: University of Alaska. p. 257-277.

Dove, H., And R. W. Mayes. 1991. The use of plant wax alkanes as marker substances in studies of the nutrition of herbivores: a review. Australian Journal of Agricultural Research 42:913-952.

Garcia-Gonzales, R. 1984. L'emploi des epidermes végétaux dans la determination du regime alimentaire de l'Isard dans les Pyrénées occidentales. Écologie des
Milieux Montagnards et de Haute Altitude. Documents d'Écologie Pyrénéenne III-IV:307-313. (In French).

GILL, G. B. 1972. Alterations of in vitro digestibility of individual deer browse species as affected by systematic mixing of paired samples [thesis]. Missoula, MT, USA: University of Montana. $82 \mathrm{p}$.

Gill, G. B., L. H. Carpenter, R. M. Bartmann, D. L. Baker, and G. G. Schoonveld. 1983. Fecal analysis to estimate deer diets. Journal of Wildlife Management 47:902-915

Guillet, C., And R. Bergström. 2006. Compensatory growth of fast-growing willow (Salix) coppice in response to simulated large herbivore browsing. Oikos 113:33-42.

HJelJoRd, 0., AND T. Histøl. 1999. Range-body mass interactions of a northern ungulate-a test of hypothesis. Oecologia 119:326-339.

Hueluord, O., N. Høvik, AND H. B. Pedersen. 1990. Choice of feeding sites by moose during summer, the influence of forest structure and plant phenology. Holarctic Ecology 13:281-292.

Hueljord, O., E. Knutsen, and S. Klasson. 1984. Underveisrapport. Elgundersøkelsene 1984. Delprosjekt A, Østfold. Ås, Norway: Department of Ecology and Natural Resource Management, University of Life Sciences. 31 p. (In Norwegian).

Hueljord, O., F. Sundstøl, and H. HaagenRud. 1982. The nutritional value of browse to moose. Journal of Wildlife Management 46:333-343.

HolecheK, J. L., AND B. D. GRoss. 1982. Training needed for quantifying simulate diets from fragmented range plants. Journal of Range Management 35:644-647.

Holechek, J. L., B. D. Gross, S. M. Dabo, and T. Stephenson. 1982. Effects of sample preparation, growth stage, and observer on microhistological analysis of herbivore diets. Journal of Wildlife Management 46:502-505.

HolecheK, J. L., and R. Valdez. 1985. Magnification and shrub stemmy material influences on fecal analysis accuracy. Journal of Range Management 38:350-353.

HubBaRD, W. A. 1952. Following the animal and eye-estimation method of measuring the forage consumed by grazing animals. In: Proceedings of the 6th International Grassland Congress; 17-23 August 1952; State College, PA, USA. Washington, DC, USA: Treasurer Finance Committee. p. 1343-1347.

Knowlton, F. F. 1960. Food habits, movement and populations of moose in the Gravelly Mountains, Montana. Journal of Wildlife Management 24:162170.

Leslie, D. M., M. Vavra, E. E. Stakkey, and R. C. Slater. 1983. Correcting for differential digestibility in microhistological analyses involving common coastal forages of the Pacific Northwest. Journal of Range Management 36:730-732.

Mayes, R. W., AND H. Dove. 2000. Measurement of dietary nutrient intake in freeranging mammalian herbivores. Nutrition Research Reviews 13:107-138.

McCullagh, P., And J. A. Nelder. 1989. Generalized linear models. 2nd ed. London, United Kingdom: Chapman and Hall. 532 p.

Ortmann, S., B. J. Bradley, C. Stolter, and J. U. Ganzhorn. 2006. Estimating the quality and composition of wild animal diets-a critical survey of methods. In: G. Hohmann, M. M. Robbins, and C. Boesch [EDS.]. Feeding ecology in apes and other primates: ecological, physical and behavioral aspects. Cambridge, United Kingdom: Cambridge University Press. p. 395-418.

Parker, D. M., and R. T. F. Bernard. 2006. A comparison of two diet analysis techniques for a browsing megaherbivore. Journal of Wildlife Management 70:1477-1480.

Pulıım, D. E. 1978. Determination of digestibility coefficients for quantification of elk fecal analysis [thesis]. Pullman, WA, USA: Washington State University. $27 \mathrm{p}$.

Sether, B.-E., S. Engen, and R. Andersen. 1989. Resource utilization of moose Alces alces during winter: constraints and options. Finnish Game Research 46:79-86.

Sather, B.-E., K. Solbraa, D. P. Sødal, and 0. Hueljord. 1992. The final report from the project "Moose - forest - society". NINA Research Report 28:1-153. (In Norwegian with English abstract).

Schoener, T. W. 1968. The Anolis lizards of Bimini: resource partitioning in a complex fauna. Ecology 49:704-726. 
Scrimgeour, G. J., and J. Winterbourn. 1987. Diet, food resource partitioning and feeding periodicity of two river dwelling fish species in a New Zealand river. Journal of Fish Biology 31:309-324.

Shipley, L. A., S. Blomquist, And K. Danell. 1998. Diet choices made by free-ranging moose in northern Sweden in relation to plant distribution, chemistry, and morphology. Canadian Journal of Zoology 76:1722-1733.

VIVÅs, H. J., AND B.-E. S Sether. 1987. Interactions between a generalist herbivore, the moose Alces alces and its food resources: an experimental study of winter foraging behaviour in relation to browse availability. Journal of Animal Ecology 56:509-520.
WalkeR, J. W., D. H. Clark, and S. D. McCoy. 1998. Fecal NIRS for predicting percent leafy spurge in diets. Journal of Range Management 51:450-455.

WARD, A. L. 1970. Stomach content and fecal analysis: methods of forage identification. Range and Wildlife Habitat Evaluation. Washington, DC, USA: US Forest Service Miscellaneous Publications No. 1147. 146 p.

Westoby, M. 1978. What are the biological bases of varied diets? American Naturalist 112:627-631.

Westoby, M., G. R. Rost, and J. A. Weis. 1976. Problems with estimating herbivore diets by microscopically identifying plant fragments from stomachs. Journal of Mammal Research 57:167-172. 